 \\ z Filologii Polskiej \\ i Słowiańskiej
}

\section{Vyjadrovanie fyzických stavov živej substancie v slovanských jazykoch}

1. Fyzický stav, do ktorého sa dostala živá substancia, mohol vzniknút ako následok pôsobenia danej či inej substancie alebo ako výsledok istého procesu či istej prechodovej zmeny. To však pre myšlienkovo-jazykové spracovania a následné jazykové stvárnenie v podobe jednoduchej vety nie je dôležité. Kedže ide o stav, substancia, ktorá sa nachádza/sa nachádzala/sa bude nachádzat' v danom stave, nemôže byt' sémanticky aktívna. Z hladiska sémantickej štruktúry vety nadobúda vo vete funkciu subjektu (skratka Sb) s neaktívnou špecifikáciou nositela stavu (skratka N stavu; Tibenská, 2012a). Jeho stvárnenie vo vete môže byt' $\mathrm{v}$ zhode s významovou štruktúrou podmetové (vo forme gramatického Sb) alebo nepodmetové (zvyčajne v tvare akuzatívu alebo datívu). Pri nepodmetovom stvárnení Sb sa formou zvýrazňuje jeho sémantická neaktívnost'.

Porovnávací výskum slovanských jazykov sa realizuje z diachrónneho i synchrónneho hladiska najmä v rovine zvukovej a lexikálnej (vrátane slovotvorby a frazeológie), menej už v oblasti morfologickej a štatisticky najmenej

This is an Open Access article distributed under the terms of the Creative Commons Attribution 3.0 PL License (creativecommons.org/licenses/by/3.0/pl/), which permits redistribution, commercial and non-commercial, provided that the article is properly cited. () The Author(s) 2017.

Publisher: Institute of Slavic Studies, Polish Academy of Sciences

[Wydawca: Instytut Slawistyki Polskiej Akademii Nauk] 
v oblasti syntaxe. Konštatovat to môžeme aj na základe výstupov z medzinárodného projektu Współczesne przemiany języków słowiańskich (1945-1995), známeho tiež ako Najnowsze dzieje języków słowiańskich, organizovaného na Univerzite v Opole profesorom S. Gajdom. Ako členke pracovnej skupiny zaoberajúcej sa v rámci tohto projektu výskumom syntaktického systému súčasných slovanských jazykov podarilo sa mi podrobne zmapovat výsledky dovtedajšieho výskumu syntaxe na Slovensku (Tibenská, 1998, pp. 81-87). Pracovnú skupinu zameranú na syntax viedol v projekte prof. S. Karolak. Jeho metódu možno nazvat sémanticko-štruktúrnou. Vychádzala zo sémantických vlastností jednotlivých predikátov a zo štruktúr, ktoré dané predikáty tvorili a ktoré sa členili podla stupňa zložitosti, odvodeného od počtu a usporiadania explicitných aj implicitných argumentov. Nebudeme sa podrobnejšie venovat' danej metóde, pretože ju vo svojej monografii o základových štruktúrach slovenskej jednoduchej vety podrobne spracúva M. Papierz (Papierz, 2013). Za istý nedostatok tejto metódy považujeme to, že spoločnou porovnávacou bázou neboli rovnaké predikáty a neskúmala sa variabilnost štruktúr, ktoré v jednotlivých jazykoch tvorili, ale vychádzalo sa z predikátovo-argumentových štruktúr, ku ktorým sa v jednotlivých jazykoch hladali vhodné reprezentujúce príklady z rôznych štýlov. Projekt sa, žial', pre chorobu a úmrtie prof. S. Karolaka nedokončil, vyriešené však boli niektoré čiastkové porovnávacie analýzy (pre bieloruštinu, bulharčinu a polštinu Kiklewicz, Korytkowska, Mazurkiewicz-Sułkowska, Zatorska, \& Ramza, 2010; pre bulharčinu a polšstinu už predtým Korytkowska, 1990, 1992).

Zatial' najucelenejšou monografiou západoslovanskej proveniencie venovanou porovnávaciemu konfrontačnému výskumu slovanskej jednoduchej vety v súčasných spisovných slovanských jazykoch je monografia českých autoriek H. Běličová a L. Uhlírová (Běličová \& Uhlírová, 1996). Autorky sa snažili opísat slovanskú vetu komplexne, preto do svojho výskumu zahrnuli jej štruktúrnu syntaktickú organizáciu, jej sémantickú výstavbu i vztahy medzi oboma štruktúrami, a navyše aj javy pragmatické. Kedže slovanské jazyky patria typologicky k jazykom flektívnym, porovnávací výskum syntaktickej štruktúry vety je u autoriek pri rozčlenenom stvárnení situácie spätý s problematikou výberu participanta do pozície podmetu, s jeho morfologickým stvárnením a s kongruentným stvárnením syntaktického predikátu, teda prísudku, d’alej s otázkami diatézy a syntaktického stvárnenia vety pri negácii. Táto čast’ výskumu je teda spätá s konfrontáciou jazykov v oblasti formy. Výskum sémantickej výstavby vety sa opiera o lexikálno-kategoriálne vlastnosti predikátu, východiskovo 
o jeho dištinktívnu vlastnost rozčlenenosṫ/nerozčlenenost predstavy o deji/ stave/vlastnosti a o vlastnost' extrovertné či introvertné zameranie príznaku. $\mathrm{V}$ chápaní autoriek však o distribúcii funkcií jednotlivých participantov nevypovedá samotný predikát, ale stvárnenie participantov jednotlivými pádmi. V prípade predložkových pádov ich funkciu charakterizujú najmä predložky (v najväčšej miere sa úloha predložiek prejavuje v bulharčine a v macedónčine). Analýza vychádza $\mathrm{z}$ typového formálneho stvárnenia participantov $\mathrm{v}$ ich jednotlivých sémantických špecifikáciách, pričom pri exemplifikácii nejde o úplný výpočet predikátov istej sémantickej skupiny ani o príklady stvárnenia viet $\mathrm{s}$ totožným predikátom $\mathrm{v}$ rôznych slovanských jazykoch. Autorky teda neuvádzajú rôznorodé významovo-formálne spracovanie typovo zhodnej situácie $\mathrm{v}$ jednotlivých jazykoch, $\mathrm{v}$ slovenčine reprezentovanou množinou viet Je mi na vracanie., Chce sa mi vracat., Napína ma na vracanie. - Chce sa mi plakat., Je mi do plaču. O formálne stvárnenie sa autorky opierajú aj pri porovnávacej analýze pragmatických javov, kam zaradujú aktuálne členenie a slovosled vetného jadra i problematiku určenosti nominálnej skupiny a vôbec vyjadrovania určenosti v slovanských jazykoch (Tibenská, 2015).

Zvyčajne sa pri porovnávacích analýzach pozornosṫ venuje iba jednotlivým javom v sémanticko-formálnej štruktúre slovanských viet. Štatisticky aj rozsahom najbohatšie je spracovaná problematika tzv. posesívneho datívu a jeho významových špecifikácií. $V$ daných analýzach sa vychádza $\mathrm{z}$ rovnakej či čiastočne modifikovanej sémantiky daného javu a konfrontujú sa odlišné formy jeho stvárnenia $\mathrm{v}$ jednotlivých slovanských (i neslovanských) jazykoch. Za všetky práce tohto typu uvedieme analýzu E. Dąbrowskej v Polsku (Dąbrowska, 1997) a M. Kyselovej na Slovensku (Kyselová, 2012), rusko-českú porovnávaciu analýzu daného javu spracovanú dávnejšie v českej jazykovede R. Zimekom (Zimek, 1960) a širšie koncipovanú prácu o kategórii posesivity a jej stvárnení v jazykoch od J. Štěpána (Štepán, 1985).

Viaceré práce západoslovanskej proveniencie sa zameriavajú na didakticky profilované porovnávacie konfrontačné analýzy zväčša dvoch slovanských jazykov, zahŕňajúce aj oblast' vetnej syntaxe. $Z$ novších takto zameraných slovensko-inojazyčných prác spomenieme učebnice Slovenčina a čeština (Sokolová, Musilová, \& Slančová, 2007) a Slovenčina a polština (Sokolová, Vojteková, Mirosławska \& Kyselová, 2012). Analýzy sa obmedzujú na formálne javy a ich funkcie, napr. na používanie neurčitých tvarov pri kondenzácii textu, pričom sa poukazuje na odlišnosti v porovnávaných jazykoch alebo na odlišnú mieru využivania zhodných syntaktických javov. 
Inšpiráciu na intrajazykovú i interjazykovú porovnávaciu analýzu vetných štruktúr sme hladali aj v prácach zameraných na významovú či formálnu alebo významovo-formálnu analýzu jednoduchých slovenských a českých viet (Tibenská, 2012a, 2012b; Kačala, 1989, 2009; Papierz, 2013; Daneš, Hlavsa, Kořenský et al., 1981), v už spomínaných porovnávacích či monolingválnych učebniciach gramatiky a syntaxe slovenčiny (Ivanová, 2011), v teoretických i učebnicových opisoch syntaktického systému jednotlivých slovanských jazykov (výberovo Grepl \& Karlík, 1998; Daneš, Grepl, \& Hlavsa, 1987; Grochowski, Karolak, \& Topolińska, 1984; Katičić, 2002; Silić \& Pranjković, 2005; Ivić, 2005; Shvedova, 1980).

Najviac inšpiratívnou bola pre nás už citovaná práca M. Grepla a P. Karlíka Skladba češtiny, z ktorej preberáme termín mikrosituácia. Nechápeme ju však ako intenčnú štruktúru istej triedy predikátorov so spoločnými kategoriálnymi príznakmi, ale širšie, situačne.

Pristúpime teraz k vlastnej porovnávacej analýze jednoduchých viet stvárňujúcich neaktívne fyzické stavy živého organizmu vo zvolených slovanských jazykoch. Východiskovým jazykom porovnávacej analýzy je slovenčina, dalšími jazykmi sú slovinčina, chorvátčina a zo západoslovanských čeština a polština. Naša metóda porovnávacej analýzy vychádza zo zisteného faktu, že poznané a myšlienkovo spracované typovo zhodné mimojazykové situácie sa $\mathrm{v}$ jednotlivých jazykových spoločenstvách myšlienkovo-jazykovo spracúvajú a rečovo prezentujú typovo zhodným spôsobom. Znamená to, že komunikujúci ludia si vnímanú a poznávanú realitu pri jej myšlienkovo-jazykovom spracovaní vždy istým spôsobom klasifikujú, typovo zaradujú. Na najvyššom stupni abstrakcie si tak vytvárajú kategórie typovo zhodných mimojazykových situácií, ktoré sú univerzálne vo všetkých jazykových spoločenstvách. Ide o kategoriálne gnozeologické či logické (kognitívne) bázy, ktoré majú hodnotu akejsi globálnej situácie. Podla našich analýz existujúcich vetných štruktúr v slovenčine (Tibenská, 2012a) sem zarad’ujeme kategórie:

- dej alebo stav ako nerozčlenená situácia,

- neaktívne (podvedomé) zmyslové vnímanie,

- neaktívne hodnotenie,

- spôsobovanie (zložené štruktúry kauzácie i iniciácie),

- stav ako rozčlenená situácia (tu aj zmena stavu, city a pocity a ich prejavy),

- vlastnost',

- relácia zahŕňania a posesívnosti,

- proces (úmyselný alebo neúmyselný), 
- pôsobenie (akcia úmyselná alebo neúmyselná),

- produkovanie,

- realizácia (samým sebou, svojou podstatou),

- existencia (tu aj lokalizácia).

Na nižšom stupni abstrakcie sa jednotlivé kategórie členia na makrosituácie, teda podrobnejšie špecifikované kognitívne bázy. Makrosituáciu definujeme ako širší výsek skutočnosti na pomerne vysokom stupni abstrakcie, ktorý sa ako samostatný významový celok vyčlenil v spoločenskom vedomí príslušníkov istého jazykového spoločenstva (Tibenská, 2015). V kategórii dej alebo stav ako formálne nerozčlenená (denotatívna) situácia môžeme napríklad vyčlenit makrosituácie atmosférické nerozčlenené deje, atmosférické nerozčlenené stavy, nerozčlenené fyzické stavy živého organizmu, nerozčlenené psychické stavy živého organizmu a pod. Myšlienkovo-jazykové spracovanie jednotlivých makrosituácií ukazuje, že aj tie sa zvyčajne ešte d’alej triedia na mikrosituácie, predstavujúce typovo zhodné obsahové bázy pre jednotlivé myšlienkovo-jazykovo spracované a stvárnené situácie. Napríklad v rámci makrosituácie „choroby živého organizmu“ môžeme vyčlenit mikrosituáciu A „získat chorobu, ochoriet", v ktorej ide o holé konštatovanie výskytu choroby u živého organizmu, mikrosituáciu $\mathrm{B}$, kde ide o vonkajšie fyzické a psychické prejavy choroby na organizme ako celku, a mikrosituáciu $\mathrm{C}$, kde ide o prejavy choroby iba na časti organizmu (Tibenská, 2015).

Každá mikrosituácia predstavuje v danom jazykovom spoločenstve myšlienkovo-jazykovo konvencionalizovaný uhol pohladu na makrosituáciu. $\mathrm{Na}$ stvárnenie jednotlivých mikrosituácií v rámci jednej makrosituácie slúžia lexikálne, gramaticky aj vztahovo odlišné, typovo však zhodné súbory významovo-formálnych jazykových štruktúr, svedčiace o myšlienkovo-jazykových obmenách istého prototypu, teda akejsi základovej vetnej štruktúry danej mikrosituácie. Termín základová vetná štruktúra nechápeme ako východiskovú z hladiska derivácií a modifikácií, ale ako prvoplánovú vo vedomí človeka, zvyčajne najlepšie vystihujúcu logiku danej situácie a zároveň ako najfrekventovanejšiu $z$ hladiska používania. Podobne uvažuje J. Kořenský, ked' komunikácia ako činnost’ producenta aktuálnych rečových aktov má v jeho koncepcii charakter výberu zo súboru prostriedkov referenčne a funkčne synonymných, pričom ide o výber riadený potrebami expedienta (Kořenský, 1984; preklad E. T.).

Všetky významovo-formálne štruktúry v rámci jednej mikrosituácie predstavujú potom celú potenciu jej myšlienkovo-jazykového spracovania a stvárnenia v danom 
jazyku. Pri jednotlivých predikátoroch (slovesách s istým vetným významom v úlohe predikátu) patriacich do totožnej mikrosituácie sa nie vždy uplatní celá potencia, teda nie všetky významovo-formálne vetné štruktúry späté s danou mikrosituáciou. Zapríčinené je to rôznorodými sémantickými obmedzeniami. Úlohou jazykovedca je tieto obmedzenia porovnaním odhalit a následne vysvetlit.

Myšlienkovo-jazykové spracovanie v rámci mikrosituácie predstavuje prepojenie jazykového významu s jazykovou formou a jej všetkými možnými obmenami, prinášajúcimi zároveň istú modifikáciu fundamentálneho významu. Porovnávaním všetkých potenciálnych vetných štruktúr pri rôznych predikátoroch v skúmanom východiskovom jazyku (v našom výskume slovenčine) potvrdzujeme naše zistenie, že $\mathrm{v}$ rámci mikrosituácie ide o štruktúry typovo zhodné. Porovnávaním s dalšími štyrmi slovanskými jazykmi v rámci jednotlivých mikrosituácií potom skúmame, ktoré z nich majú významovo-formálne vetné štruktúry zhodné, prípadne čím sa od seba odlišujú alebo ktoré štruktúry sa v istom jazyku realizujú a v inom nie. Posledným krokom je vysvetlovanie možných príčin odlišností v skúmaných jazykoch.

2. Predmetom našej štúdie je intrajazyková aj interjazyková porovnávacia analýza myšlienkovo-jazykového spracovania a stvárnenia makrosituácie „neaktívne fyzické stavy živej substancie“, patriaca do kategórie „stav ako rozčlenená situácia (tu aj zmena stavu a jeho prejavy)“.

2.1. Prvou mikrosituáciou, ktorá je kontextovo podmienená a spracúva celkový fyzický stav živého ludského organizmu, je „pocitovaný všeobecný fyzický stav organizmu ako celku“. Variabilita vetných štruktúr v tejto mikrosituácii je minimálna. V slovenčine je stvárnená vetami Je mi dobre. - opozitne Je mi zle., opisne Cítim sa dobre - zle. Prototypová (typická, najviac frekventovaná) veta s datívne stvárneným nositelom stavu (skratka Nst) je formálne jednočlenná, s vetnou schému $\mathrm{VF}_{\text {cop impers. }}+\mathrm{ADV}_{\bmod }-\mathrm{PRON}_{\mathrm{D}}$, čo zvýrazňuje významovú neaktívnost' subjektu (skratka Sb). Vetu Cítim sa dobre - zle. s vetnou schémou $\left(\mathrm{PRON}_{\mathrm{N}}\right)-\mathrm{VF}_{\text {refl }}-\mathrm{ADV}$, v ktorej je už Sb stvárnený podmetovo, teda vo východiskovej pozícii a v tvare nominatívu, môžeme za sémanticky neaktívnu považovat iba na základe lexikálnej sémantiky predikátora a s ním obligatórne spätého adverbia.

Pri interjazykovej komparatívnej analýze, v rámci ktorej porovnávané jazyky uvádzame v poradí slovenčina, čeština, poľština, chorvátčina, slovinčina, vidíme, že vetná štruktúra s datívne stvárneným Sb v slovinčine chýba 
(nevýskyt vetnej štruktúry označujeme nulou, málo frekventovaný výskyt označujeme hviezdičkou). Jediný prostriedok na formálne stvárnenie neaktívnosti je tu slovosled vo vete Dobro - slabo se počutim. oproti východiskovo stvárnenému zamlčanému podmetu vo vete Počutim se dobro - slabo. Kedže ide o typovo odlišnú vetnú štruktúru v porovnaní s ostatnými jazykmi, uvádzame ju v zátvorke. V chorvátčine sa veta s datívne stvárneným Sb vyskytuje, ale oproti západoslovanským jazykom rovnako ako v slovinčine je slovosledne (a pri rečovej realizácii vetným prízvukom) zvýraznená kvalita pocitu (dobro). Celková interjazyková komparatívna analýza danej mikrosituácie vyzerá takto:

Je mi dobre. - Cítim sa dobre.

Je mi dobře. - Cítím se dobře.

Jest mi dobrze. - Czuję się dobrze.

Dobro mi je. - Osjećam se dobro.

0 (Dobro se počutim.) - Počutim se dobro.

Zhodné vetné štruktúry slúžia na stvárnenie celkového psychického stavu organizmu, preto iba z kontextu či situácie vieme, či ide o fyzický alebo psychický stav organizmu. Ak v sponovo-mennom vetnom základe namiesto adverbií so všeobecným kladným či záporným významom (dobre - zle) použijeme adverbium s konkrétnejším významom, potom sa vetné štruktúry vo všetkých porovnávaných jazykoch obmedzia iba na prvý typ s datívne stvárneným Nst:

Je mi zima. - Je mi horúco. (obrazne: Horím.).

Je mi zima. - Je mi horko. (obrazne: Hořím.)

Jest mi zimno. - Jest mi gorąco. (obrazne: Płonę.)

Hladno mi je. - Vruće mi je. (obrazne: Gorim.)

Zebe me. - Vroče mi je. (obrazne: Gorim.)

Len čo by sme chceli stvárnit’ mikrosituáciu „pocitovaný fyzický stav na časti organizmu“, počet potenciálnych vetných štruktúr by sa rozšíril. Okrem vetných štruktúr s fakultatívne prítomným pomenovaním časti organizmu (ruky) vo vetných štruktúrach typu Je mi zima (na ruky). - ${ }^{\star} J e$ mi teplo (na tvár). sa v slovenčine pri pocite chladu môžu vyskytovat štruktúry so slovesom oziabat' a obligatórnym výskytom pomenovania časti tela: Oziabajú ma ruky. / Oziaba ma na ruky. - Mám ladové/zmrznuté ruky., pri pocite tepla so slovesom horiet: Horí mi tvár. / Horím v tvári. - Mám horúcu/rozpálenú tvár. Rovnaká situácia by nastala $\mathrm{v}$ porovnávaných jazykoch.

Je mi zima (na ruky). - Oziabajú ma ruky. - Oziaba ma (na ruky). - Mám ladové/zmrznuté ruky. 
Je mi zima (na ruce). - Zebou mě ruce. - 0 - Mám ledové/zmrznuté ruce. Jest mi zimno (w ręce). - Ziębna mi ręce. - 0 - Mam lodowate/zmarznięte ręce. Hladno mi je (za ruke). - Zebu mi ruke. - Zebe me (za ruke). - Imam ledene/smrznute ruke.

Zebe me (v roke). - 0 - 0 - Imam ledene/zmrznjene roke.

2.2. Druhá mikrosituácia je $\mathrm{v}$ istom zmysle rozšírením predchádzajúcej, pretože ide o „pocitovaný celkový stav organizmu počas vykonávania istej činnosti“. Vety tohto typu nazývame v slovenskej jazykovede vetami dispozičného typu (stvárňujú, akú dispozíciu mám na vykonávanie istej činnosti). Vo vetnej štruktúre formálne jednočlennej vety sa namiesto kopuly uplatňuje plnovýznamové sloveso pomenúvajúce danú činnost', adverbium si zachováva svoju obligatórnost'. Kým pri aktívnej činnosti, sémanticky špecifikovanej ako proces (Ide sa mi dobre - zle.), nie je v slovenčine možné obsahové usúvztažnenie s vetou s podmetovo stvárneným Sb (Idem dobre. - Idem zle.), pretože by sa zmenil význam na aktívny („idem správnym smerom“), pri neaktívne, mimovol'ne vykonávanom procese je takáto obsahová usúvzṫažnenosṫ možná (Spalo sa mi dobre. - Spal som dobre.). Pri porovnaní s ostatným jazykmi vidíme, že podobne ako v predchádzajúcej situácii chorvátčina a slovinčina používajú v obidvoch prípadoch iba vety s podmetovo stvárneným Sb, veta Spalo se mi je dobro. je v slovinčine zriedkavá (označené znamienkom*). Pol'ské vetné štruktúry sa odlišujú slovosledom enklitík (v slovenčine a češtine sú enklitiky na druhom mieste vo vete). Na otázku Jak ci się spało? by bola odpoved'Spało mi się dobrze., kým bezkontextovo by mala veta slovoslednú podobu Dobrze mi się spało.

Ide sa mi zle. - 0

Spalo sa mi výborne. - Spal som výborne.

Jde se mi výborně. - 0

Spalo se mi výborně. - Spal sem výborně.

Idzie mi się dobrze. - 0

Spało mi się znakomicie. - Spałem dobrze.

0 - Dobro hodam.

0 - Odlično sam spavala.

Dobro hodim.

*Spalo se mi je dobro. - Dobro sem spal.

2.3. Tretou mikrosituáciou je „pocitovaný špecifikovaný fyzický stav organizmu ako celku“. Oproti všeobecnému stavu dobre - zle slúžia na jazykové stvár- 
nenie špecifikovaného fyzického stavu organizmu viaceré vetné štruktúry. Prototypová veta Eva je unavená. je svojou štruktúrou zhodná s vetami stvárňujúcimi vlastnost' (Eva je dobrá.). O tom, že Sb je špecifikovaný ako Nst a nie $\mathrm{N}$ vlastnosti, nás presviedčajú obsahovo synonymné vetné štruktúry so slovesom cítim/cítim sa v úlohe predikátu (Eva cíti únavu., Eva sa cíti unavene.). Porovnávané jazyky vykazujú vzácnu zhodu. V chorvátčine a češtine chýba jedna a v slovinčine všetky obrazné vetné štruktúry stvárňujúce pocit (únavu) ako realizátora činnosti (vo vetách Evu premohla únava. / Evy sa zmocnila únava.) či dokonca pri doslovnej interpretácii ako jeho procesora ( $\mathrm{Na}$ Evu ide/expr. lezie únava.). Navyše z hladiska slovosledu sa v prvej porovnávanej vetnej štruktúre chorvátčina a slovinčina, teda južnoslovanské jazyky, odlišujú od všetkých ostatných porovnávaných západoslovanských jazykov (kopula v nich nestojí na začiatku vety).

Som unavená. - Cítim únavu. - Cítim sa unavene. - (obrazne: Premohlal Zmocnila sa ma únava. - Ide/expr. lezie na mňa únava.)

Jsem unavená. - Cítím únavu. - Cítím se unaveně. - (obrazne: Přemohla/ Zmocnila se mě únava. - 0)

Jestem zmęczona. - Odczuwam zmęczenie. - Czuję się zmęczona. - (obrazne: Pokonało/Opanowało mnie zmęczenie. - Dopada mnie zmęczenie.)

Umorna sam. - Osjećam umor. - Osjećam se umorno. - (obrazne: Savladao/Hvata me umor. - 0)

Utrujena sem. - Čutim utrujenost. - Počutim se utrujeno. - (obrazne: 0/0 - 0)

2.4. O podrobnejšiu špecifikáciu stavu ide aj pri štvrtej analyzovanej mikrosituácii charakterizovanej ako „pocitovaný fyzický stav organizmu zapríčinený nedostatkom jedla/tekutín“. Prototypová veta je Eva je hladná., synonymne aj Eva je lačná., typovo zhodne Eva je smädná. Formálnou stránkou $\left(\mathrm{S}_{\mathrm{N}}-\mathrm{VF}_{\text {cop }}+\right.$ $\mathrm{ADJ}_{\mathrm{N}}$ ) sú tieto vety zhodné s vetami analyzovanými v predchádzajúcej mikrosituácii a vetami slúžiacimi na stvárnenie vlastností (Eva je dobrá.). Že ide o stav, nie o vlastnost', nás presviedčajú ostatné vety stvárňujúce rovnakú mikrosituáciu: Eva má prázdny žalúdok/prázdne brucho., Eva má hlad., Eve sa chce/žiada jest., Eva chce jest'. V nich sa namiesto kopuly používa sloveso mat'v spojení s abstraktným substantívom (hlad, smäd) alebo neosobný zvratný tvar slovies chciet', žiadat. Iba posledná vetná štruktúra Eva chce jest'. má formálne aktívny charakter, používaný aj pri stvárnení vôle konat akýkolvek iný dej (Eva chce písat'). Obrazne stvárnené prejavy hladu - škŕkanie v žalúdku či tma pred očami - uvádzame v zátvorke. Stav pocitovania vel'kej miery hladu obsahujú vety Eva trpí hladom. - Eva umiera od hladu. Stav náhleho pocitu hladu sa v slovenčine vyjadrí vetou Evy sa zmocnil hlad. 
Medzijazykovou komparáciou zistujeme, že veta so slovesom mat'a s posesívnym odtienkom Eva má hlad. sa vyskytuje iba v slovenčine a v češtine. Veta s neosobným zvratným tvarom slovies chciet'a žiadat' (Chce sa mi. / Žiada sa mi jest.) sa nevyskytuje v češtine ani v slovinčine, v chorvátčine sa vyskytuje iba prvá z nich, avšak so zmeneným poradím enklitík (Jede mi se.).

Som hladná/lačná. - Mám prázdny žalúdok/prázdne brucho. - Mám hlad. Chce sa mi/Žiada sa mi jest'. - Chcem jest. - (obrazne: Škŕka mi v žalúdku od hladu., Tmie sa mi pred očami od hladu.). - Trpím hladom. / Trápi ma hlad. Umieram od hladu. - Zmocnil sa ma hlad.

Jsem hladná. - Mám prázdný žaludek. - Mám hlad. - 0 - Chci jíst. (obrazne: 0 - 0) - Trpím hlady. / 0 - Umírám hlady. - Zmocnil se mě hlad.

Jestem głodna. - Mam pusty żołądek/pusty brzuch. - 0 - Chce mi się jeść. I Pragnę (coś) zjeść. - Chce jeść. - (obrazne: Burczy mi w brzuchu z głodu., Robi mi się ciemno przed oczami z głodu.) - Cierpię głód. - Umieram z głodu. Opanowat mnie głód.

Gladna sam. - Prazan mi je želudac/trbuh. - 0 - Jede mi se./0 - Želim jesti. (obrazne: Krulji mi u želucu od gladi., Mrači mi se pred očima od gladi.) Patim od gladi. - Umirem od gladi. - Primila me glad.

Lačna sem. - Imam prazen želodec/prazen trebuh. -0 - 0/0 - Želim jesti. (obrazne: Od lakote mi kruli v želodcu., Temni se mi pred očmi od lakote.) - Muči me lakota. - Umiram od lakote. - 0

Typovo zhodne sa stvárňuje stav, ked’ živý organizmus pocituje nedostatok tekutín. V porovnaní s predchádzajúcim stavom hladu je pri stave smädu v slovenčine aj v slovinčine možná aj vetná štruktúra s akuzatívne stvárneným pomenovaním Sb so špecifikáciou Nst Smädí ma. - Žeja me. V polšstine na to musíme použit iné sloveso: Suszy mnie. a v chorvátčine je dokonca možné tento význam stvárnit iba formálne aktívnou vetnou štruktúrou Žeđam. Naopak, veta typu Mám smäd. je v slovenčine menej častá ako veta Smädí ma., v polštine je zriedkavá, v slovinčine i chorvátčine sa nevyskytuje, kým v češtine je veta Mám žizeň. vel’mi frekventovaná. Kým aktívne stvárnená veta Zmocnil sa ma hlad. s abstraktným substantívom hlad v úlohe $S b$ so špecifikáciou realizátor (podla Tibenská, 2012a) vo všetkých porovnávaných jazykoch okrem slovinčiny možná je, pri abstrakte smäd chýba, resp. v slovenčine je iba zriedkavá.

Som smädná. - Smädí ma. - Mám vyschnuté/sucho v ústach. - Mám smäd. - Chce sa mi/Žiada sa mi pit. - Chcem pit. (obrazne: Jazyk sa mi lepí od smädu.) - Trpím smädom. - Umieram od smädu. - ${ }^{\star} Z$ mocnil sa ma smäd. 
Jsem žíznivá. - 0 - Mám vyschlo/sucho v ústech. - Mám žízeň. - 0/0 - Chci pít. (obrazne: 0) - Trpím žízní. - Umírám žízní. - 0

Jestem spragniona. - Suszy mnie. - Mam sucho $w$ ustach. - ${ }^{*}$ Mam pragnienie. - Chce mi się/Pragnę pić. - Chce pić. (obrazne: Język przysecht mi do podniebienia.) - 0 - Umieram z pragnienia. -

Žedan sam. - 0 (Žeđam.) - Usta su mi suha. - 0 -0/0 - Želim piti. (obrazne: Jezik mi se lijepi od žeđi.) - Trpim žeđ. - Umirem od žeđi. - 0

Žejen sem. - Žeja me. - V ustih imam sušo/suho. - 0 - Rad bi pil./0 - Hočem piti. - (obrazne: Jezik se mi od žeje lepi na nebo.) - Trpim žejo. - Umiram od žeje. -0

2.5. Obsahovou obmenou predchádzajúcej mikrosituácie je piata analyzovaná mikrosituácia, spätá s fyzickým stavom, ktorý môžeme vystihnút ako „stav žiadostivosti (vy)pit konkrétny nápoj (kávu, pivo, víno...) alebo zjest’ nejaký druh jedla či konkrétne jedlo (sladké, slané, polievku...)“. Komparáciou zistujeme, že najviac sa pri stvárňovaní danej mikrosituácie od ostatných jazykov odlišujú vety v slovinčine. Vetnú štruktúru s datívne stvárneným $\mathrm{N}$ stavu tu nachádzame iba vo vete Lušta se mi kave., ktorá sa však vyskytuje iba $\mathrm{v}$ hovorovom štýle. Ostatné s ňou obsahovo späté vety majú sloveso v tvare kondicionálu alebo patria tiež do hovorového štýlu. Vetné štruktúry s polyverbalizovanými výrazmi mat' chut', dostat' chut'v úlohe predikátu sa v slovinčine nevyskytujú. V chorvátčine sa datívne stvárnený Nst nachádza iba vo frekventovanej hovorovej vete Pije mi se kava. Neutrálne sa tento význam vyjadruje kondicionálom slovesa chciet'(Htio bih kavu.). Polšstina síce datívne stvárnený Sb zachováva, namiesto slovesa žiadat' však v úlohe predikátu vystupuje sloveso chciet' (Chce mi się kawy.). Na rozdiel od slovenčiny je sloveso chciet $\mathrm{v}$ úlohe predikátu v neosobnom zvratnom tvare, čím sa zvýrazňuje neaktívnost' Sb. Veta s datívne stvárneným Nst sa nevyskytuje v češtine. Naopak, čeština má vetu s polyverbizovaným výrazom dostat chut v úlohe predikátu, ktorá sa nevyskytuje nielen $\mathrm{v}$ slovinčine, ale ani v polšstine a chorvátčine.

Žiada sa mi káva. - Mám chut na kávu. - Mám chut vypit si kávu. - Dostala som chut na kávu.

0 - Mám chut na kávu. - Mám chut vypít kávu. - Dostal jsem chut na kávu.

Chce mi się kawy. - Mam ochotę na kawę. - Mam ochotę wypić kawę. - 0 hovor. Pije mi se kava. (Htio bih kavu.) - Imam želju za kavom. - Imam želju popiti kavu. -0

hovor. Lušta se mi kave. (Pila bi kavo. / Rad bi (spil) kavo. / hovor. Rabim kavo. / Potreben sem kave.) $-0-0-0$ 
Typovo zhodné štruktúry sú pri žiadostivosti po jedle. Vo východiskovom jazyku slovenčine pribudla k prototypovej vetnej štruktúre so slovesom žiadat'v neosobnom zvratnom tvare synonymná vetná štruktúra s neosobným slovesom zachcelo sa. Takáto vetná štruktúra chýba $\mathrm{v}$ češtine, $\mathrm{v}$ polšstine je predikát žiada sa rovnako ako v prípade pitia nahradený predikátom chce sa. V tomto prípade slovenčina používa zriedkavo vetné štruktúry Chce sa mi jest' niečo sladké. a Mám chut zjest' niečo sladké. Preto ich označujeme hviezdičkou. Chorvátčina ani slovinčina vetnú štruktúru s datívom Nst nemajú, tentoraz ani v hovorom štýle. No kým pri tekutine sa vety s polyverbizovaným spojením dostat chut'v týchto jazykoch nevyskytovali, pri jedle je v chorvátčine takáto vetná štruktúra možná, i ked’ je menej frekventovaná (Dobio sam želju za nečim slatkim.). Aj v polšstine je namiesto vetnej štruktúry so spojením dostałem ochotę prirodzenejšia vetná štruktúra so spojením nabrałem ochoty.

Žiada sa mi niečo sladké. / Zachcelo sa mi niečo sladké/niečoho sladkého. Mám chut' na niečo sladké. - ${ }^{*}$ Mám chut' (z)jest' niečo sladké. / ${ }^{*}$ Chce sa mi (z) jest' niečo sladké. - Dostal som chut na niečo sladké.

*Žádá se mi něco sladkého. / 0 - Mám chut na něco sladkého. - Mám chut sníst něco sladkého. - Dostal jsem chut na něco sladkého.

Chce mi się czegośs słodkiego. / Zachciało mi się czegośsłodkiego. - Mam ochotę na coś słodkiego. - Chcę zjeść coś słodkiego. - Nabrałem ochoty na coś słodkiego.

0/0 - Imam želju za nečim slatkim. - Želim jesti nešto slatko. - Dobio sam želju za nečim slatkim.

0 (Rad bi nekaj sladkega. / Hočem nekaj sladkega.) - 0 - Hočem jesti nekaj sladkega. -0

2.6. S prvou analyzovanou mikrosituáciou úzko súvisí šiesta mikrosituácia „fyzický stav zdravia - choroby organizmu“ (dobre mi je/dobre sa fyzicky cítim vtedy, ked’ som zdravý). Všeobecný stav zdravia - choroby organizmu ako celku vystihujú vety: Ivan je chorý. - Ivan je zdravý. Na vystihnutie prechodovej zmeny zo stavu, ked' bol človek zdravý, do stavu, ked’ je organizmus ako celok chorý, slúži veta Ivan ochorel. V porovnávaných jazykoch sa vyskytujú analogické vetné štruktúry:

$\begin{array}{lll}\text { Ivan je zdravý. } & \text { - chorý. } & \text { - Ivan ochorel. } \\ \text { Ivan je zdravý. } & \text { - nemocný. } & \text { - Ivan onemocněl. } \\ \text { Ivan jest zdrowy. } & \text { - chory. } & \text { - Ivan zachorowat. } \\ \text { Ivan je zdrav. } & \text { - bolestan. } & \text { - Ivan je obolio. } \\ \text { Ivan je zdrav. } & \text { - bolan. } & \text { - Ivan je zbolel. }\end{array}$


3. Ak chceme chorobu konkretizovat', počet vetných štruktúr narastie. Prototypovou štruktúrou bude posledná $\mathrm{z}$ predchádzajúcich typov vetných štruktúr rozšírená o fakultatívny člen pomenúvajúci konkrétnu chorobu. Jeho stvárnenie sa mení od bezpredložkového v češtine k predložkovému evokujúcemu význam modusu (v slovenčine, polšstine a slovinčine) až po význam príčiny ( $\mathrm{v}$ chorvátčine). $\mathrm{O}$ tom, že ide o stav, nás presviedčajú sémanticky neaktívne vetné štruktúry so slovesom mat'a dostat' a prenesene aj so slovesom (neúmyselne) chytit: Ivan má/dostal/chytil chrípku. V slovinčine štruktúra s preneseným významom slovesa chytit chýba. Aj vetné štruktúry so slovesami mat'a dostat' sú v porovnávaných južnoslovanských jazykoch zriedkavé. Obrazne, z pozície participanta chrípka ako realizátora, ktorý sebou, svojou podstatou realizuje dej zameraný na paciensa, je stvárnený daný stav vo vete Skolila ho/Premohla ho chrípka. V polštine by tu bola najtypickejšou vetná štruktúra Nabawit się grypy.

Ivan ochorel (na chrípku). - Ivan má/dostal/chytil chrípku. - Skolila ho/ Premohla ho chrípka.

Ivan onemocněl (chřipkou). - Ivan má/dostal/chytil chřipku. - Skolila ho/ Přemohla ho chřipka.

Ivan zachorował (na grypę). - Ivan mal/*dostał/złapał grypę. - ${ }^{*}$ Skosiła go/Pokonała go grypa.

Ivan je obolio (od gripe). - ${ }^{\star}$ Ivan ima/dobio je/uhvatio je gripu. - Napala /Savladala ga je gripa.

Ivan je zbolel (za gripo). - Ivan ima/dobil/0 gripo. - Položila ga je/0 gripa.

Typovo zhodné vetné štruktúry nájdeme aj pri iných ochoreniach (angína, osýpky, zápal plúc a pod.). Ak však ide o neinfekčnú a zvyčajne náhlu chorobu, prvá vetná štruktúra sa realizovat nemôže ( ${ }^{\star}$ Ivan ochorel na infarkt., ${ }^{*} I v a n$ ochorel na porážku.). Z rovnakých dôvodov chýba aj vetná štruktúra so slovesom chytit. Veta s realizátorom má hovorový a súčasne expresívny charakter: hovor. expr. Trafil ho šlak. Možné sú teda iba vetné štruktúry Trafil ho šlak., Porazilo ho., Mal/Dostal/Prekonal infarkt. V polštine pôjde o analogické štruktúry Szlag go trafit., Sparaliżowało go., Ma zawał. / Dostał zawału/apopleksii. / Przeszedt zawat. V chorvátčine je možný iba tretí typ štruktúry: Imao/Dobio/Prebolio je infarkt/srčani ili moždani udar. (podrobnejšie Tibenská, 2015).

Ak je organizmus v štádiu tesne pred ochorením, opät sa na vystihnutie tohto stavu používajú typovo zhodné vetné štruktúry. Obidve majú značne obrazný charakter, formálne v nich totiž zaujíma východiskovú podmetovú 
pozíciu názov choroby: Ivana sa chytá chrípka. - hovor. expr. Na Ivana lezie chrípka. Rovnako je to v porovnávaných jazykoch, s tým rozdielom, že niektorá z uvedených dvoch vetných štruktúr môže byt zriedkavá (v polštine) alebo chýba:

Ivana sa chytá chrípka. - hovor. expr. Na Ivana lezie chrípka.

0

Ivana chwyta grypa.

Ivana hvata gripa. 0
- hovor. expr. Na Ivana leze chřipka.

- hovor. ${ }^{\star} \mathrm{Na}$ Ivana idzie grypa.

$-0$

$-0$

Ak ide o neinfekčnú, náhlu chorobu, potom sa štádium tesne pred ochorením v slovenčine stvárni datívnym tvarom pomenovania Nst a kopulou v spojení so slovesným substantívom v úlohe predikátu (Je mi na porazenie., synonymne, ale štylisticky príznakovo aj hovor. expr. Je mu na šlak trafenie.) alebo limitnými slovesami ist', mat'v spojení s infinitívom plnovýznamového slovesa a s akuzatívnym stvárnením Nst (Ide/Má ho porazit.). Prvá vetná štruktúra sa používa aj pri silnom citovom pohnutí, ked' je človek na niečo velmi nahnevaný (a $\mathrm{z}$ toho dôvodu je blízko infarktu). Pri interjazykovom porovnaní vidíme, že v češtine a polšstine sú možné iba vetné štruktúry s budúcim časom slovesa alebo opisným vyjadrením blízkosti stavu (v polšstine). V južnoslovanských jazykoch sa takéto štruktúry nevyskytujú (v zátvorke uvádzame v chorvátčine významovo najbližšie štruktúry.) .

Je mu na porazenie. / hovor. expr. Je mu na šlak trafenie. - Ide/Má ho porazit'. 0 / hovor. expr. Trefí mě šlak. - 0

Jest bliski apopleksji. / expr. Chyba go krew zaleje. - 0

0 (Loše mu je.) - 0 (Pozlit će mu.)

$0-0$

Pri tejto mikrosituácii zvyčajne istému náhlemu ochoreniu či náhlej negatívnej zmene stavu organizmu predchádzajú isté príznaky. Tak napríklad fyzickému stavu „zamdlenia/straty vedomia“ zvyčajne predchádza stav stvárnený ako „točenie hlavy“. Vzniká tak množina vetných štruktúr s datívne alebo podmetovo stvárneným Nst. Interjazyková komparácia ukazuje, že úplná zhoda nastáva pri tretej vetnej štruktúre s polyverbalizovaným spojením strácat' vedomie $\mathrm{v}$ úlohe predikátu. Iba čiastočná zhoda v porovnávaných jazykoch sa vyskytuje pri prvej štruktúre, ktorá pomenúva príznak predchádzajúci vzniku negatívneho fyzického stavu zamdlenia. Aj v nej je však formálne v slovenčine, češtine a slovinčine podmetom vety čast' organizmu - hlava -, kým organizmus ako celok je stvár- 
nený datívom evokujúcim význam posesívneho benefaktora (Tibenská, 2012a). V polštine a chorvátčine sa na stvárnenie totožnej situácie používa bezpodmetová veta s datívne stvárneným Nst (pomenovaním organizmu ako celku), pričom čast' organizmu nadobúda v súlade s formou význam komplementu so špecifikáciou lokus. Obidva spomenuté jazyky sa zhodujú aj v poradí enklitík.

Druhý a štvrtý typ vetnej štruktúry je zhodný iba v slovenčine a češtine, $\mathrm{v}$ polšstine opät limit tesne pred nastaním negatívnej zmeny stavu musíme vyjadrit' opisne (Jestem bliski omdlenia., Chyba zemdleję.), chorvátčina a slovinčina musí na to použit tvar budúceho (alebo prítomného) času.

Toči sa mi hlava. - Je mi na zamdlenie. - Strácam vedomie. - Idem zamdliet.

Točí se mi hlava. - Je mi na omdlení. - Ztrácím vědomí. - *Jdu omdlít. / Omdlím.

Kręci mi się w głowie. - Jestem bliski omdlenia. - Tracę świadomość. Chyba zemdleję.

Vrti mi se u glavi. - Onesvijestit ću se. - Gubim svijest. - Onesvijestit ću se.

Vrti se mi glava. - 0 (Omedlevam.) - Izgubljam zavest. - Omedlel bom.

Najčastejším prejavom choroby je bolest', ktorá sa sústred’uje v mieste ochorenia a zasahuje organizmus ako celok. Prvá vetná štruktúra Bolia ma kríže. stvárňuje choré miesto ako kauzátora, spôsobujúceho bolest’ organizmu ako celku (vo vete objekt so špecifikáciou paciens). V druhom a tretom type vetnej štruktúry je už choré miesto $\mathrm{v}$ zhode s poznaním reality stvárnené ako komplement so špecifikáciou locus a chorý organizmus je Sb so špecifikáciou Nst. Predikátom je polyverbizované spojenie cítim bolest', mám bolesti. Najväčšia miera neaktívnosti je obsiahnutá vo štvrtom vetnom type s predikátom mat'. Porovnávané jazyky vykazujú vzácnu zhodu vetných štruktúr. Rozdiely sú iba minimálne - slovinčina má v druhej vetnej štruktúre vo východiskovej pozícii locus, $v$ polšstine chýba štvrtá vetná štruktúra.

Bolia ma kríže. - Cítim bolest’v krížoch. - Mám bolesti v krížoch. - Mám bol'avé kríže.

Bolí mě záda. - Cítím bolest v zádech. - Mám bolesti v zádech. - Mám bolavá záda.

Boli mnie krzyż. - Czuję ból w krzyżu. - Mam bóle w krzyżu. - 0

Bole me križa. - Osjećam bol u križima. - Imam bolove u križima. - Imam bolna križa.

Boli me križ. - V križu čutim bolečino. - Bolečine imam v križu. - Boleč križ imam. 
Obmenou bolesti je ostrá bolest’ - pichanie či klanie. Uvedené deverbatíva neumožňujú tvorbu adjektív, preto odpadá štvrtý typ vetnej štruktúry. Rovnako tak sa nekombinujú so slovesom mat', čo je dôvodom nerealizácie tretieho typu vetnej štruktúry. Ostatné dve vetné štruktúry sú typovo zhodné s predchádzajúcimi príkladmi.

Pichá ho srdce/pri srdci. - Pichá/Kole ma bok/v boku.

Píchá ho u srdce. - Píchá mě v boku.

Kłuje go w sercu/w okolicy serca. - Kłuje mnie w boku.

Probada ga srce/u srcu. - Probada ga bok/u boku.

Zbada me pri srcu. - Zbada me v boku.

Prostredníctvom opísanej metódy, ktorú sme predstavili na analýze šiestich mikrosituácií súvisiacich s makrosituáciou „fyzické stavy ludského organizmu“, je možné predstavit’ a opísat rôznorodé makro- a mikrosituácie späté s istou obsahovou bázou - kategóriou -, ukázat rôznorodost' a zároveň typovú zhodnost' ich myšlienkovo-jazykového spracovania a stvárnenia v jednom jazyku (pri intrajazykovej analýze) a tiež porovnat výsledky tejto analýzy s typovou zhodnostou ich myšlienkovo-jazykového spracovania a stvárnenia v inom jazyku či v iných jazykoch (pri interjazykovej komparatívnej analýze). Prirodzene, výsledky oboch typov analýz sa dajú využit aj didakticky, najmä vo vyučovaní cudzích jazykov alebo vo vyučovaní materinského jazyka ako cudzieho. Pedagóg sa pri jej uplatnení môže cielene zamerat najmä na výklad a precvičovanie kontrastívnych vetných štruktúr v rámci mikro- či makrosituácie.

\section{Bibliografia}

Běličová, H., \& Uhlířová, L. (1996). Slovanská věta. Praha: Euroslavica.

Daneš, F., Grepl, M., \& Hlavsa, Z. (Eds.). (1987). Mluvnice češtiny (3). Skladba. Praha: Academia.

Daneš, F., Hlavsa, Z., Kořenský, J. et al. (1981). Větné vzorce v češtině. Praha: Academia.

Dąbrowska, E. (1997). Cognitive semantics and the Polish Dative. Berlin: Mouton de Gruyter. https://doi.org/10.1515/9783110814781

Grepl, M., \& Karlík, P. (1998). Skladba češtiny. Brno: Votobia.

Grochowski, M., Karolak, S., \& Topolińska, Z. (1984). Gramatyka współczesnego języka polskiego: Część 1. Składnia. Warszawa: Państwowe Wydawnictwo Naukowe.

Ivanová, M. (2011). Syntax slovenského jazyka. Prešov: Vydavatel'stvo Prešovskej univerzity. 
Ivić, M. (Ed.). (2005). Sintaksa savremenoga srpskog jezika: Prosta rečenica. Beograd: Institut za srpski jezik SANU, Beogradska kniga, Matica srpska.

Kačala, J. (1989). Sloveso a sémantická štruktúra vety. Bratislava: Veda, vydavatel’stvo Slovenskej akadémie vied.

Kačala, J. (2009). Dvojčlenné a jednočlenné vety v slovenčine. Martin: Matica slovenská.

Katičić, R. (2002). Sintaksa hrvatskoga književnog jezika (3., rozšírené vydanie). Zagreb: Nakladni zavod Globus, Hrvatska akademija znanosti i umjetnosti.

Kiklewicz, A., Korytkowska, M., Mazurkiewicz-Sułkowska, J., Zatorska, A., \& Ramza, T. (2010). Podstawowe struktury zdaniowe współczesnych języków słowiańskich: białoruski, bułgarski i polski. Olsztyn: Centrum Badań Europy Wschodniej Uniwersytetu Warmińsko-Mazurskiego.

Korytkowska, M. (1990). Z problematyki składni konfrontatywnej-na przykładzie bułgarskich i polskich zdań bezpodmiotowych. Wrocław: Zakład Narodowy im. Ossolińskich. (Prace Slawistyczne, 82)

Korytkowska, M. (1992). Typy pozycji predykatowo-argumentowych. Warszawa: Slawistyczny Ośrodek Wydawniczy. (Gramatyka konfrontatywna bułgarsko-polska, 5)

Kořenský, J. (1984). Konstrukce gramatiky ze sémantické báze. Praha: Academia.

Kyselová, M. (2012). Sémantický a syntaktický status posesívneho datívu v štruktúrach s procesnými slovesami s významom atmosférického diania v slovenčine. Jazykovedný časopis, 63(2), 131-152.

Papierz, M. (2013). Podstawowe struktury składniowe współczesnego języka słowackiego. Kraków: LEXIS.

Shvedova, N. I. (Ed.). (1980). Russkaia grammatika: Vol. 2. Sintaksis. Moskva: Nauka.

Silić, J. \& Pranjković, I. (2005). Gramatika hrvatskoga jezika za gimnazije i visoka učiličša. Zagreb: Školska knjiga.

Sokolová, M., Musilová, K., \& Slančová, D. (2007). Slovenčina a čeština. Bratislava: Univerzita Komenského.

Sokolová, M., Vojteková, M., Mirosławska, W. \& Kysel’ová, M. (2012). Slovenčina a polšstina. Prešov: Filozofická fakulta Prešovskej univerzity.

Štěpán, J. (1985). Ke kategorii posesivity a jejímu ztvárnění v jazicích. Slovo a slovesnost, (1), 20-27.

Tibenská, E. (1998). Zmeny v jazykových podsystémoch (čiastkových normách): Syntaktická rovina. In J. Bosák (Ed.), Najnowsze dzieje języków słowiańskich: Slovenskýjazyk (pp. 81-87). Opole: Uniwersytet Opolski - Instytut Filologii Polskiej.

Tibenská, E. (2012a). Sémantická štruktúra slovenskej vety. Trnava: Univerzita sv. Cyrila a Metoda v Trnave, Filozofická fakulta.

Tibenská, E. (2012b). Slovenčina v zrkadle vnútorných a vonkajších vztahov: Slovački jezik u zrcalu unutrašnjih $i$ vanjskih odnosa. Zagreb: FF press.

Tibenská, E. (2015). Metodológia porovnávacieho výskumu jednoduchých viet. In H. Mieczkowska, E. Solak, P. Fałowski, \& N. Palich (Eds.), Tradycja i wyzwania: Metodologia badań 
slawistycznych XX i XXI wieku (pp. 187-195). Kraków: Wydawnictwo Uniwersytetu Jagiellońskiego.

Zimek, R. (1960). K chápání posesivnosti. In Rusko-české studie: Sborník Vysoké školy pedagogické v Praze: Jazyk a literatura, 2 (pp. 131-154). Praha: Vysoká škola pedagogická.

\section{Expressing physical conditions of a living substance in Slavic languages}

\section{Summary}

The article presents a new a didactically conditioned method of description and explanation of simple Slavic sentences. The approach is based on the comparative research of a common base, constituted by a congruent semantic logical-gnoseological structure, which I term the "macro-situation." This macro-situation consists of several micro-situations, which constitute different viewing angles of the macro-situation's thought-linguistic processing. The depiction of a micro-situation is constituted by congruent types of semantic-formal structures, which represent the existing variations as well as the thought-linguistic potential.

\section{Wyrażanie fizycznych warunków żywych substancji w językach słowiańskich}

\section{Streszczenie}

Artykuł przedstawia nową, nastawioną dydaktycznie metodę opisu i analizy prostych zdań w językach słowiańskich. Podejście to opiera się na porównawczej analizie wspólnej podstawy. Podstawa ta przedstawia sobą strukturę logiczno-gnozeologiczną, którą nazywam „makrosytuacją”. Każda makrosytuacja dzieli się na pewną liczbę mikrosytuacji, stanowiących różne myślowo-językowe 
punkty widzenia na daną makrosytuację. Na opis mikrosytuacji składają się przystające typy struktur semantyczno-formalnych, zarówno występujące w języku, jak i potencjalne.

Keywords: thought-linguistic processing of situations; category; micro-situation; macro-situation; congruent types of semantic structures; comparative method

Słowa kluczowe: myślowo-językowe opracowanie sytuacji; kategorie; mikrosytuacja; makrosytuacja; przystające typy struktur semantycznych; metoda porównawcza

Eva Tibenská, Department of Slovak Language and Literature, Faculty of Philosophy, University of Ss. Cyril and Methodius, Trnava / Department of Slavistics, Faculty of Arts, University of Ljubljana, Ljubljana Correspondence: tibenska57@gmail.com

The article was prepared at the author's own expense.

Competing interests: The author has declared she has no competing interests. 